\title{
Anatomy of of Suprascapular Notch among North Indian Dry Scapulae: A Morphological Evaluation
}

\section{Susmita Saha ${ }^{1}$, Shilpi Garg ${ }^{2}$, Kirandeep Kaur' ${ }^{1}$ Prachi Saffar Aneja ${ }^{3}$}

Section: Healthcare

Sci. Journal Impact

Factor: $6.1(2018)$

ICV: 90.90 (2018)

(c) (7) (8)

Copyright@IJCRR

\author{
'Associate Professor, Department of Anatomy, Faculty of Medicine \& Health Sciences, SGT Medical College, Budhera, Gurgaon-122505, \\ India; 'Assistant Professor, Department of Anatomy, Faculty of Medicine \& Health Sciences, SGT Medical College, Budhera, Gur- \\ gaon-122505, India; 'Professor \& Head, Department of Anatomy, Faculty of Medicine \& Health Sciences, SGT Medical College, Budhera, \\ Gurgaon-122505, India.
}

\section{ABSTRACT}

Background: The suprascapular notch (SSN) is a depression located in the lateral portion of the upper border of the scapula encroached by the superior transverse scapular ligament. It may be completely or partially ossified to transform the notch into a foramen which acts as a gateway for the passage of the suprascapular nerve.

Methods: Two hundred \& ninety adult dry scapulae (132 right \& 158 left) from the osteology museum of the Department of Anatomy, belonging to North Indian population of unknown sex were obtained for the variable morphologic pattern of SSN by subjective evaluation according to Rengachary's classification. We have also examined the morphological variant of the ossified superior transverse suprascapular ligament (STSL).

Results: We have concluded six different morphological variations of SSN. Among them, the Type III SSN had the highest incidence of $41.7 \%$. Morphological variability was noted for the ossified STSL: fan-shaped \& band like; morphometric analysis was also performed for the completely ossified STSL. The incidence of different types of ossified STSL was $57.5 \%$ (fan-shaped); $42.2 \%$ (band-like) category respectively \& the mean length, width, thickness of the STSL were $7.49 \mathrm{~mm} ; 3.43 \mathrm{~mm} \& 2.18 \mathrm{~mm}$ respectively. The mean length \& width of complete suprascapular foramen were $7.36 \mathrm{~mm}$ and $4.39 \mathrm{~mm}$ respectively.

Conclusions: SSN shows highly variable morphological pictures, so the clinicians are desirable to be well versed with the diverse appearance of such anatomic variants of SSN on dry bones so that they can interpret its morphology on radiographs and MRI scans. This evaluation may be of great help for academicians and orthopaedic surgeons for the diagnosis \& treatment modalities of suprascapular nerve entrapment syndrome.

Key Words: Scapula, Suprascapular notch, Morphology, Ossified suprascapular ligament, Suprascapular nerve, Entrapment syndrome

\section{INTRODUCTION}

The scapula, a flat triangular bone, articulates with the distal end of the clavicle and humeral head and has numerous muscular and ligamentous attachments. ${ }^{1}$ Anatomical considerations are central in understanding specific abnormalities such as glenohumeral dislocation, entrapment neuropathies etc. Detailed morphological variations of different parts of the scapula have been obtained to provide information for surgical procedures such as hardwire fixation, arthroscopic portal placement, and treatment of nerve compression syndrome. ${ }^{1}$ The bone bears a thick spinous process (spine of the scapula) in the dorsal surface which divides it into a small supraspinous fossa $\&$ large infra spinous fossa. ${ }^{2}$ Along with the supraspinous fossa, the superior border; the thinnest \& smallest margin of the scapula runs. Close to the root of the coracoid process, this thinnest upper border of the scapula is interrupted by a suprascapular notch. ${ }^{3}$ The notch is bridged by the superior transverse scapular ligament (STSL) which serves as a passage for the suprascapular nerve. ${ }^{3,4}$ The STSL sometimes gets partially or completely ossified converting the notch into a foramen. Whenever there is the formation of complete foramen; it becomes a potential source for the entrapment neuropathy. ${ }^{3,5}$ The suprascapular nerve is a mixed nerve that arises from the upper trunk of brachial plexus containing roots from $\mathrm{C} 5$ \& $\mathrm{C} 6 .{ }^{6,7}$ The nerve innervates the shoulder joint as well as the supraspinatus, infraspinatus muscles which make a bigger contribution in the musculotendinous cuff., Compression of the suprascapular nerve along its course can lead to entrapment neuropathy or suprascapu-

\section{Corresponding Author:}

Dr. Susmita Saha C/O Tapas Saha; DDA flat 8- C, pocket 10 B, Block 7, Jasola, New Delhi, 110025, India.

Email: drsusmita.sh@gmail.com

ISSN: 2231-2196 (Print)

Received: 10.07 .2020
ISSN: 0975-5241 (Online)

Revised: 11.09 .2020
Accepted: 18.10 .2020 
lar nerve entrapment syndrome (SNES), first described by Kopell \& Thompson in $1959 .{ }^{8}$ They also described the clinical features of this neuropathy which comprises deep, dull, diffuse pain on the posterolateral part of the shoulder with weakened abduction of the shoulder joint. The root cause for the symptom was progressive atrophy of supraspinatus \& infraspinatus muscle supplied by the suprascapular nerve. ${ }^{9}$ It has been observed that the morphological variation of SSN is one of the predisposing factors for the nerve entrapment, especially in players $\&$ athletes. ${ }^{10}$ Among the different classification of the SSN morphology, Rengachary's classification is the most popular one which has been accepted by different population group throughout the world. ${ }^{11}$ So, knowledge for the SSN variations may be essential for the etiopathogenesis of the SNES. Not only variable morphology of the notch but also the different variety of STSL will also serve as a potential factor for the entrapment syndrome. The clinicians should be aware of this type of morphological variations while diagnosing SNES \& performing nerve decompression as a part of treatment. To the best of our knowledge, most of the studies regarding this theory have been performed in the western population as well as southern India. Very few studies have been done in the North Indian population. So, it is expected that the study of morphological variations of SSN \& ossified transverse scapular ligament in the North Indian population will serve as a reference base. Considering the increasing number of such cases, it is expected to facilitate the surgeons in the assessment and management of such patients of entrapment syndrome.

\section{MATERIALS AND METHODS}

The present observational study conducted on Two hundred and ninety adult dry scapulae of unknown sexes from the osteology museum, department of Anatomy. The exact age of the specimens was not known but was estimated as the mature adult individuals (the specimens were anonymised, randomly coded and delinked from any identity sources, ICMR National guidelines for biomedical \& health research involving human participants, ICMR, 2017, sec 5, Box 5.2). The scapulae with broken or damaged superior border were excluded from the study. The general inspection was done to determine the Side of the dry scapulae. We performed subjective evaluation (visual inspection) on the scapulae for the morphologic pattern of suprascapular notch according to Rengachary's classification ${ }^{11}$ which has been shown in Table 1.

Along with the various pattern of SSN, we have also examined the morphological variants and morphometric parameters of ossified STSL which convert the SSN into a foramen. The morphometric evaluation was performed by the help of a digital vernier calliper for the ossified STSL \& suprascapular foramen. Proper photography was done for the documen- tation of the observations.

\section{Statistical analysis}

In the present study, data were analyzed in Microsoft Excel to determine the incidence as percentages. For each morphometric parameters, maximum; minimum; mean and standard deviation were also calculated. Though it was a descriptive type of analysis, so test of significance was not applied. Our observations for the incidence of different category of SSN \& STSL were compared with other osteological studies performed on different population groups.

\section{RESULTS}

Among 290 adult dry scapulae studied, 132 bones belonged to right side \& 158 bones were of the left side. By visual inspection, we have categorized six different morphological variations of SSN according to Rengachary'sclassification. ${ }^{11}$ The incidence of the various types of SSN observed in the present study: Type I (24.82\%), Type II (12\%), Type III (41.7\%), Type IV (10\%), Type VI (11.37\%). We did not observe any Type V SSN in our study. The result has been shown in Figure 1. The morphologic pattern of SSN has been displayed in Figure 2 (A: type I; B: type II; C: type III; D: type IV \& E: type V; F: type VI).

We have observed the incidence of completely ossified STSL leading to suprascapular foramen in 33 scapulae (11.37\%). Out of 33 scapulae, 19 scapulae $(57.5 \%)$ was fan-shaped; 14 scapulae $(42.2 \%)$ belonged to band like a category that has been shown in Figure 3. The mean value of ossified STSL length is $7.49 \mathrm{~mm}$; width is $3.43 \mathrm{~mm}$, the thickness is $2.18 \mathrm{~mm}$ among the 33 scapulae with ossified STSL as mentioned in Table 2. The mean value of the length of the complete suprascapular foramen is $7.03 \mathrm{~mm} \&$ width is $4.39 \mathrm{~mm}$. This has been represented in Table 3. Morphological variations of STSL have been displayed in Figure 4 (A band like; B fan-shaped).

\section{DISCUSSION}

Suprascapular nerve entrapment can occur at the SSN or the spinoglenoid notch. So, morphological variations of the SSN are associated with entrapment neuropathies \& arthroscopic procedures. ${ }^{12}$ That is why the variations in the shape of notch \& the course of the nerve is extremely important in realizing the etiopathogenesis of entrapment syndrome \& these anatomic variations are considered to be a risk factor for suprascapular neuropathy. The oldest classification of the suprascapular notch was introduced by Hrdlicka et al., who separate the suprascapular notches into five types based on visual observations. ${ }^{13}$ Ticker et al. mentioned only about $\mathrm{U}$ and $\mathrm{V}$-shaped notch types. ${ }^{14}$ Natsis et al. proposed a new 
method of classification based on specific geometric parameters..$^{15}$ The most popular $\&$ widely accepted classification is the Rengachary's classification, who described the six types of notches performed among the Americans. ${ }^{11}$ Wang et al. in $2011^{16}$, described four types of notches according to a simple method; that is the type I ( wide depression); type II ( transverse diameter of the notch is much more than vertical diameter); type III ( vertical diameter is the longest); type IV ( suprascapular foramen). Some of the authors also described different alphabetical shaped SSN among Indian population like shallow U, deep U, V-shaped, J shaped \& slightly indented notch. ${ }^{17-20}$ In our study, the incidence was the highest in type III (Symmetrical 'U') followed by type I ( a wide depression), then type II ( wide blunt ' $V$ '). Our results agree with previous studies. ${ }^{11,12,15,21,22}$ Some of the suthorsPatil et al. ${ }^{23}$, Dusyant et al. ${ }^{24}$ have reported the highest incidence of type IV (pointed ' $\mathrm{V}$ ' shaped). Most of the studies by other researchers have reported about partially ossified STSL leading to incomplete suprascapular foramen which was only $1.03 \%$ in our observation almost similar to Patil et al. ${ }^{23}$. Partial presence of suprascapular foramen was seen. ${ }^{11,12,17,20,22,25}$ We have reported complete foramen with ossified STSL in $11.37 \%$ scapulae. Incidence of different morphological variations of the suprascapular notch in different population has been displayed in Table 4.

The SSN is converted into a suprascapular foramen by the STSL through which the suprascapular nerve passes \& suprascapular vessels pass above the foramen. ${ }^{3}$ Conventional textbooks have also reported about partial \& completely ossified STSL as a cause of nerve entrapment syndrome leading to severe pain \&disabilities ${ }^{3,29,30}$. The incidence of such ossified anatomic structure has been documented in different states of the Indian population by other authors have been shown in Table 5 .

Apart from the bony inspection, Das et al. in 2007 correlated the ossified STSL in the radiograph ${ }^{31}$. In the present study, we have reported $11.37 \%$ of complete ossification of STSL. Our result agrees with Bayramoglu et al. in Turkish population. ${ }^{10}$ Among different regions in India, our result is almost the same as studies done by Jadhav et al. ${ }^{32}$ and Kharay et al. ${ }^{34}$ Our result for the incidence of suprascapular foramen has been analyzed with another population group that has been displayed in Table 6. Rest of the studies the incidence was quite less. Wang et al. ${ }^{16}$, reported unique scapulae with double suprascapular foramen. In 2015, the morphological variations of ossified STSL; fan-shaped \& band like were only first observed by Polguj et al. in $2014{ }^{35}$. In India, it was described by Kharay et al. ${ }^{34}$ in 2016. In 2019, our study has highlighted the variable morphology of ossified STSL as fan-shaped \& band like among the North Indian which has been shown in Table 7. Our results are similar to the other two authors but the number of dry bones in our study is the highest. To the best of our knowledge, though many studies have been performed to find out the incidence of ossified STSL in different population group except Kharay et al. ${ }^{34}$, none of the research work has been described the variable morphology of ossified STSL along with its morphometric parameters among North Indian population. Apart from that, it has been observed that very few studies have been undertaken for the morphometric parameters of the suprascapular foramen which is a potential anatomic area for suprascapular nerve entrapment syndrome. So, it is expected that our study results performed on a large number of the sample will act as a reference base for the variable morphology of suprascapular notch among the North Indian population.

\section{CONCLUSION}

This morphological study on the anatomy of the suprascapular notch is very helpful as it is the commonest site for the nerve compression. The clinician especially orthopaedic surgeons \& radiologist needs to be well versed with the appearance of suprascapular notch on dry bones, so that he can interpret its morphology on radiographs and MRI scans. The morphologic \& morphometric data will help them to correlate the association between entrapment neuropathy \& variable morphology of the suprascapular notch which will assist them to decide the modality of the treatment.

\section{ACKNOWLEDGEMENT}

We wish to convey our sincere thanks to Dr. R. K. Suri, Former Director Professor \& Head, Department of Anatomy, Vardhman Mahavir Medical College for his constant inspiration in writing the research article. The authors are also grateful to publishers \& authors of all those articles and books from where the literature for this article has been reviewed and discussed.

\section{REFERENCES}

1. Von Schroeder HP, Kuiper SD, Botte MJ. Osseous Anatomy of the Scapula. Clin Orthop Res 2001; 383: 131-39.

2. McMinn RMH. Last's Anatomy. $9^{\text {th }}$ ed. UK edition: Churchill Living stone, 2009, p 68

3. Standring S, Ellis h, Healy J, Johnson D, William A. Pectoral girdle, shoulder region \& axilla. Gray's anatomy- The anatomical Basis of clinical practice. $39^{\text {th }}$ ed. New York: Elsevier Churchill Livingstone; 2005: 821-2

4. Ahmed SM. Morphometry of suprascapular notch in Egytian dry scapulae \& its correlation with measurements of suprascapular nerve safe zone for clinical consideration. Eur J Anat 2018; 22 (6): 441-448.

5. Moore KL, Dalley AF, Agur AM. Clinically oriented anatomy. Lippincott Williams \& Wilkins 2013.

6. Vorster W, Lannge CP, Briet RJ, Labuschagne BC, Dutoit DF, Muller CJ. The sensory branch of the suprascapular nerve: An 
anatomic study. J Shoulder Elbow Surg 2008; 17 (3): 500-2.

7. Molony DC, Gheit AC, Kennedy J, green C, Schepens A, Mullett $\mathrm{HJ}$, A cadaveric model for suprascapular nerve injury during glenoid component screw insertion in reverse - geometry shoulder arthroplasty. J Shoulder Elbow Surg 2011; 20(8): 1323-27.

8. Kopell H. Thompson W. Pain and the frozen shoulder. Surg Gynecol Obstet 1959; 109 (1): 92- 96.

9. Cummins CA, Meser TM, Nuber GW. Suprascapular nerve entrapment. J Bone Joint Surg 2000; 82: 415-424.

10. Bayramoglu A, Demiryurek D, Tuccar E, Erbil M, Aldur MM, Tetik $\mathrm{O}$, et al. Variations in the anatomy of suprascapular notch possibly causing suprascapular nerve entrapment: An anatomical study. Knee Surg Sports Trauma Arthrose 2003; 11: 393-98.

11. Rengachary SS, Burr D, Lucas S, Hassanein KM, Mohn MP, Matzke H. Suprascapular entrapment neuropathy: a clinical, anatomical \& comparative study. Part 2: anatomical study: Neurosurgery $1979 ; 5:$ 447-51.

12. Reddy M. A Study on the morphology of the suprascapular notch and its distance from the glenoid Cavity. J Clin Diagn Res 2013;7(2):189-92.

13. Hrdicka A. The adult scapula: additional observations and measurements. Am J Phys Antropol. 1942; 29: 363-415.

14. Ticker JB, Djurasovic M, Strauch RJ, April EW, Pollock RG, Flatow EL, et al. The incidence of ganglion cysts and other variations in anatomy along the course of suprascapular nerve. $\mathrm{J}$ Shoulder Elbow Surg. 1998; 7: 472-78.

15. Natsis K, Totlis T, Tsikaras P, Appell H, Skandalakis P, Koebke J. Proposal for classification of the suprascapular notch: A study on 423 dried scapulas. Clin Anat 2007; 20(2): 135-139.

16. Wang HJ, chen C, Wu LP, Pan CQ, Zhang WJ, Li YK. Variable morphology of the suprascapular notch: An investigation and quantitative measurements in the Chinese population. Clin Anat 2011; 24(1): 47-55.

17. Vedha S, Vidhulatha K. A Morphological Study of Suprascapular Notch and Incidence of Ossification of Superior Transverse Scapular Ligament in South Indian Dry Scapulae. Int J Curr Res Rev 2017; 9(13): 45-49.

18. Kour M, Gupta S. Morphology of the suprascapular notch of scapula \& its clinical implications. JK Science 2016; 8 (1): 3134.

19. Fatima N, Rahman S, Kumar B. A morphological study of the suprascapular notch in the population of Bihar. Ann Int Med Den Res 2017; 3(4): 1-5.

20. Gupta S, Patel Z, Howale D. A study on morphometry and morphological variation of the suprascapular notch in the dried human scapula. Int J Anat Radiol Surg 2017; 6(3): 5-9.

21. Sinkeet S, Awori K, Odula P, Ogeng'o J, Mwachaka P. The suprascapular notch: Its morphology and distance from the glenoid cavity in a Kenyan population. Folia Morphol, 2010; 69(4): 241245.

22. Kannan U, Kannan NS, Anbalagan J, and Rao S. Study of Suprascapular Notch in Indian Dry Scapulae with Specific Reference to the Incidence of Completely Ossified Superior Transverse Scapular Ligament. J Clin Diagn Res. 2014 Mar; 8(3): $7-10$.
23. Patel P, Patel SV, Patel SM, Jotania B, Chavda S, Patel D. Study of variation in the shape of the suprascapular notch in the dried human scapula. Int J Bio Med Res. 2013; 4 (2): 3162-3164.

24. Agrawal D, Singh B, Agrawal G. Human scapulae: suprascapular notch morphometry\& variations. Indian J Clin Anat Physiol 2014; 1 (1): 1-7.

25. Soni G, Malik V, Shukla L, Chabbra S, Gaur N. Morphometric analysis of the suprascapular notch. Internet J Biol Anthropol 2012; 5(1): 20-27.

26. Iqbal K, Iqbal $\mathrm{R}$, Khan $\mathrm{S}$. Anatomical variations in the shape of the suprascapular notch of the scapula. J Morphol Sci 2010; 27(1): 1-2.

27. Paolo A, Stefano S, Vittorio C, Valerio A, Rita VA, Stefano G. Morphometry of the suprascapular notch: correlation with scapular dimensions and clinical relevance. BMC Musculoskeletal Disord 2013; 14:172.

28. Vasudha TK, Ashwija S, Sadashivana G, Rajasekhar S. Morphological study on suorascapular notch and superior transverse scapular ligaments in human scapulae. J Med Res Health Sci. 2013; 2 (4): 793-798. 35.

29. Osuagwu F, Imosemi CIO, Shokunbi MT. Complete ossification of the superior transverse scapular ligament in a Nigerian male adult. Int J Morphol 2005; 23(2):121-22.

30. Cohen SB, Dines DM, Moorman CT. Familiar calcification of the superior transverse scapular ligament causing neuropathy. Clin Orthop Relat Res 1997; 334: 131-135.

31. Das S, Suri R, Kapur V. Ossification of Superior Transverse Scapular Ligament and its Clinical Implications. Sultan Qaboos Uni Med J 2007; 7 (2): 157-160.

32. Jadhav SD, Patil RJ, Roy PP, Ambali MP, Doshi MA. Supra scapular foramen in Indian dry scapulae. NJC. 2012; 1(3):133-5.

33. Kharay S, Sharma A, Singh P. Unusual morphology of scapulae: incidence \& dimensions of ossified ligaments \& supraspinous bony tunnels for clinical considerations. Singapore Med J 2016; 57 (1): 29-32.

34. Polguj M, Sibinski M, Grzegorzewski A, Waszczykowski M, Majos A, Topol M. Morphological and radiological study of ossified superior transverse scapular ligament as potential risk factor of suprascapular nerve entrapment. Biomed Res Int. 2014: 6: 601-13.

35. Mahato RK, Suman P. Ossification of superior transverse scapular ligament: incidence, etiological factors and clinical relevance. Int J Health Sci Res. 2013; 3 (9): 14-21.

36. Desai R, Ambali M, Doshi M A. Incidence of ossification of superior transverse scapular ligament of scapula in Indian population., Int J Curr Microbiol App Sci 2014; 3(9), 1080-1084.

37. Vallois HV. L'os acromial dans les races humaine. L'anthropologie. 1925; 35: 977-1022.

38. Edelson JG. Bony bridges and other variations of the suprascapular notch. J Bone Joint Surg Br. 1995; 77: 505-06.

39. DJ Gray. Variations in human scapulae. Am J Physical Anthropol 2013; 29 (1)57-59.

40. Pushpa NB, Bajpe R, Shubha R. Completely ossified suprascapular ligament - A case report. IJCRR 2013; 5 (17): 79- 81. 
Table 1: Rengachary'sclassification of suprascapular notches of the scapula"

\begin{tabular}{|c|c|c|c|c|c|}
\hline Type of suprascapular Notch & \multicolumn{5}{|c|}{ Features describing the shape of the notch } \\
\hline Type I & \multicolumn{5}{|c|}{ A wide depression from the medial superior angle to the base of the spine } \\
\hline Type II & \multicolumn{5}{|c|}{ A wide blunted V-shaped notch along the superior border at the scapula } \\
\hline Type III & \multicolumn{5}{|c|}{ Asymmetrical U shape } \\
\hline Type IV & \multicolumn{5}{|c|}{ A small V-shaped notch with a very shallow groove } \\
\hline Type V & \multicolumn{5}{|c|}{ Partial ossification of STSL } \\
\hline Type VI & \multicolumn{5}{|c|}{ Complete ossification of STSL converting notch into a bony foramen } \\
\hline Parameters & Total no $(\mathrm{N})$ & $\begin{array}{l}\text { Maximum } \\
(\mathrm{mm})\end{array}$ & $\begin{array}{l}\text { Minimum } \\
(\mathrm{mm})\end{array}$ & $\begin{array}{l}\text { Mean } \\
(\mathbf{m m})\end{array}$ & Standard deviation \\
\hline STSL length & 33 & 11.47 & 5.36 & 7.4981 & 1.5158 \\
\hline STSL width & 33 & 5.15 & 2.01 & 3.4318 & 0.9084 \\
\hline STSL thickness & 33 & 3.21 & 1.08 & 2.1887 & 0.6114 \\
\hline
\end{tabular}

Table 3: Descriptive statistic of the morphometric parameters of the suprascapular foramen

\begin{tabular}{lccccc} 
Parameters & Total no $(\mathbf{n})$ & $\begin{array}{c}\text { Maximum } \\
(\mathbf{m m})\end{array}$ & $\begin{array}{c}\text { Minimum } \\
(\mathbf{m m})\end{array}$ & $\begin{array}{c}\text { Mean } \\
(\mathbf{m m})\end{array}$ & $\begin{array}{c}\text { Standard } \\
\text { deviation }\end{array}$ \\
\hline Length of suprascapular foramen & 33 & 12.04 & 3.01 & 7.0369 & 2.3307 \\
Width of suprascapular foramen & 33 & 10.17 & 2.17 & 4.3927 & 2.1611 \\
\hline
\end{tabular}

Table 4: Comparative analysis of suprascapular morphology

\begin{tabular}{|c|c|c|c|c|c|c|c|c|c|}
\hline Authors & Year & Population & $\begin{array}{l}\text { Number of } \\
\text { scapulae }\end{array}$ & $\begin{array}{c}\text { Type I } \\
\%\end{array}$ & $\begin{array}{c}\text { Type II } \\
\%\end{array}$ & $\begin{array}{c}\text { Type III } \\
\%\end{array}$ & $\begin{array}{c}\text { Type IV } \\
\%\end{array}$ & $\begin{array}{c}\text { Type } \\
\%\end{array}$ & $\begin{array}{c}\text { Type VI } \\
\%\end{array}$ \\
\hline $\begin{array}{l}\text { Rengachary et } \\
\text { al.1 }\end{array}$ & 1979 & American & 211 & 8 & 31 & 48 & 3 & 6 & 4 \\
\hline Natsis et al. ${ }^{15}$ & 2007 & Greek & 423 & 6 & 24 & 40 & 13 & 11 & 6 \\
\hline Sinkeet et al. ${ }^{21}$ & 2010 & Kenyan & 138 & 22 & 21 & 29 & 5 & 18 & 4 \\
\hline Iqbal et al. ${ }^{26}$ & 2010 & Rawalpindi & & 26.8 & - & 13.2 & 20 & 22 & - \\
\hline Wang et al. ${ }^{16}$ & 2011 & Chinese & 295 & $9 \cdot 5$ & 58.16 & 28.23 & - & - & 4.08 \\
\hline Soni et al. ${ }^{25}$ & 2012 & Indian & 100 & 5 & 72 & 20 & & & 3 \\
\hline Albino et al. ${ }^{27}$ & 2013 & Italian & 500 & - & 19.8 & 22.8 & 31.1 & - & - \\
\hline Vasudha et al. ${ }^{28}$ & 2013 & Indian & 115 & 7.82 & 6.08 & 34.78 & - & 19.13 & - \\
\hline Reddy et al. ${ }^{12}$ & 2013 & $\begin{array}{l}\text { South Indian } \\
\text { (Andra Pradesh) }\end{array}$ & 104 & 21.15 & 8.65 & 59.61 & 2.89 & $5 \cdot 76$ & 1.93 \\
\hline Patil et al. ${ }^{23}$ & 2014 & South Indian & 112 & 20.54 & 14.29 & 25 & $35 \cdot 71$ & 1.79 & 2.68 \\
\hline Fatima et al. ${ }^{19}$ & 2014 & Bihar & 226 & 4.87 & 31.86 & 35.84 & $5 \cdot 75$ & 21.68 & - \\
\hline Kannan et al. ${ }^{22}$ & 2014 & $\begin{array}{l}\text { South Indian } \\
\text { (Pondicherry) }\end{array}$ & 400 & 20 & 10 & 52 & 4 & 4 & 10 \\
\hline $\begin{array}{l}\text { Dushyant et } \\
\text { al. }^{24}\end{array}$ & 2014 & Jodhpur & 293 & 12.28 & - & 45 & 23.54 & - & - \\
\hline Kour et al. ${ }^{18}$ & 2016 & Jammu & 60 & 13.33 & 8.33 & 46.67 & 28.33 & - & 3.33 \\
\hline Vedha et al. ${ }^{17}$ & 2017 & $\begin{array}{l}\text { South Indian } \\
\text { (Madurai) }\end{array}$ & 250 & 21.2 & 16 & 37.2 & 5.6 & 5.2 & 9.2 \\
\hline Gupta et al..$^{20}$ & 2017 & Gujarat & 120 & 10 & $7 \cdot 5$ & 24 & 50 & 5 & 2.5 \\
\hline Present study & 2019 & North Indian & 290 & 24.82 & 12 & 41.7 & 8.96 & 1.03 & 11.37 \\
\hline
\end{tabular}


Table 5: The incidence of ossified STSL has been documented in a different state of the Indian population

\begin{tabular}{|c|c|c|c|c|c|}
\hline \multirow[t]{2}{*}{ Authors } & \multirow[t]{2}{*}{ Year } & \multirow[t]{2}{*}{$\begin{array}{l}\text { Population } \\
\text { studied }\end{array}$} & \multirow[t]{2}{*}{$\begin{array}{l}\text { No of scapulae } \\
\text { studied }\end{array}$} & \multicolumn{2}{|c|}{$\begin{array}{l}\text { Incidence of completely } \\
\text { ossified STSL }\end{array}$} \\
\hline & & & & No of scapulae (N) & Percentage (\%) \\
\hline Das et al. ${ }^{31}$ & 2007 & Delhi & Single case & 1 & \\
\hline Soni et al. ${ }^{25}$ & 2012 & Agroha & 100 & 3 & 3 \\
\hline Jadhav et al. ${ }^{32}$ & 2012 & & 350 & 37 & 10.57 \\
\hline Reddy et al. ${ }^{12}$ & 2013 & Andhra Pradesh & 104 & 2 & 1.93 \\
\hline Mahato et al. ${ }^{36}$ & 2013 & Tamilnadu & 122 & 6 & 4.92 \\
\hline Kannan et al. ${ }^{22}$ & 2014 & Pondicherry & 400 & 40 & 10 \\
\hline Desai et al. ${ }^{37}$ & 2014 & Maharashtra & 194 & 5 & $9 \cdot 7$ \\
\hline Patil et al. ${ }^{23}$ & 2014 & Kerala & 112 & 3 & 2.68 \\
\hline Kour et al. ${ }^{18}$ & 2016 & Jammu & $6 o$ & 2 & 3.3 \\
\hline Kharay et al.34 & 2016 & Punjab & 268 & 26 & $9 \cdot 7$ \\
\hline Vedha et al. ${ }^{17}$ & 2017 & Madurai & 250 & 23 & 9.2 \\
\hline Present study & 2019 & North India & 290 & 33 & 11.37 \\
\hline
\end{tabular}

Table 6: Incidence of suprascapular foramen among different population groups

\begin{tabular}{|c|c|c|c|c|}
\hline Authors & Year & Population & $\begin{array}{c}\text { No Specimen studied (dry } \\
\text { scapulae) }\end{array}$ & $\begin{array}{l}\text { Incidence of suprascapular } \\
\text { foramen } \%\end{array}$ \\
\hline Vallois et al..$^{8}$ & 1926 & French & 200 & 6.5 \\
\hline Hrdicka et al. ${ }^{13}$ & 1942 & Native American & 2792 & $2.1-2.9$ \\
\hline Rengacherry et al. " & 1979 & American & 211 & 4 \\
\hline Edilson et al. ${ }^{39}$ & 1995 & American & 700 & 3.7 \\
\hline Ticker et al. ${ }^{14}$ & 1998 & American & 79 & 1.27 \\
\hline Bayramoglu et al. ${ }^{10}$ & 2003 & Turkish & 36 & 12.5 \\
\hline Ouagwu et al. ${ }^{29}$ & 2005 & Nigerian & \multicolumn{2}{|c|}{ Single case } \\
\hline Natsis et al. ${ }^{15}$ & 2007 & Greek & 423 & 6 \\
\hline Sinkeet et al. ${ }^{21}$ & 2010 & Kenyan & 138 & 4 \\
\hline Wang et al. ${ }^{16}$ & 2011 & Chinese & 295 & 1.36 \\
\hline DJ grayº & 2013 & American \&Europian & 1151 & 6.34 \\
\hline Pushpa NB ${ }^{41}$ & 2013 & Indian & \multicolumn{2}{|c|}{ Single case } \\
\hline Paolo Albino et al. ${ }^{27}$ & 2013 & Italian & 500 & 3.6 \\
\hline Polguj et al. ${ }^{35}$ & 2014 & Poland & 86 & 6 \\
\hline Ahmed et al. ${ }^{4}$ & 2018 & Egypt & 65 & 3.08 \\
\hline Present study & 2019 & India & 290 & 11.37 \\
\hline
\end{tabular}

Table 7: Incidence of variations in ossified STSL morphology

\begin{tabular}{lllccc} 
Authors & Year & Population & $\begin{array}{c}\text { No of scapulae with os- } \\
\text { sified STSL / total no of } \\
\text { the scapula }\end{array}$ & Type of ossified STSL \\
& & & & $\begin{array}{c}\text { Fan-shaped } \\
\text { STSL N (\%) }\end{array}$ & $\begin{array}{c}\text { Band like } \\
\text { STSL N (\%) }\end{array}$ \\
\hline Polguj et al. 35 & 2014 & Poland & $6 / 86$ & $4(4.7 \%)$ & $2(2.3 \%)$ \\
Kharay et al.34 & 2016 & India & $26 / 268$ & $16(61.5 \%)$ & $10(38.5 \%)$ \\
Present study & 2019 & India & $33 / 290$ & $19(57.5 \%)$ & $14(42.2 \%)$ \\
\hline
\end{tabular}




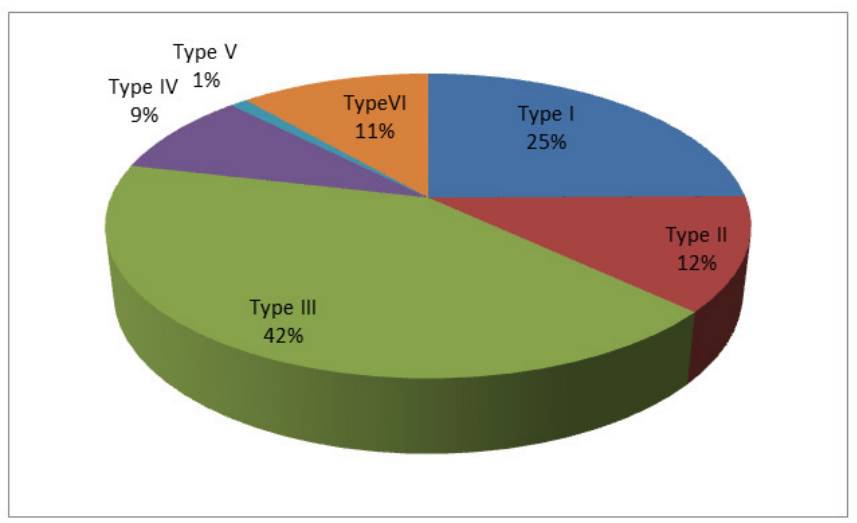

Figure 1: Graphical representation of the incidence of various types of the suprascapular notch in the present study.
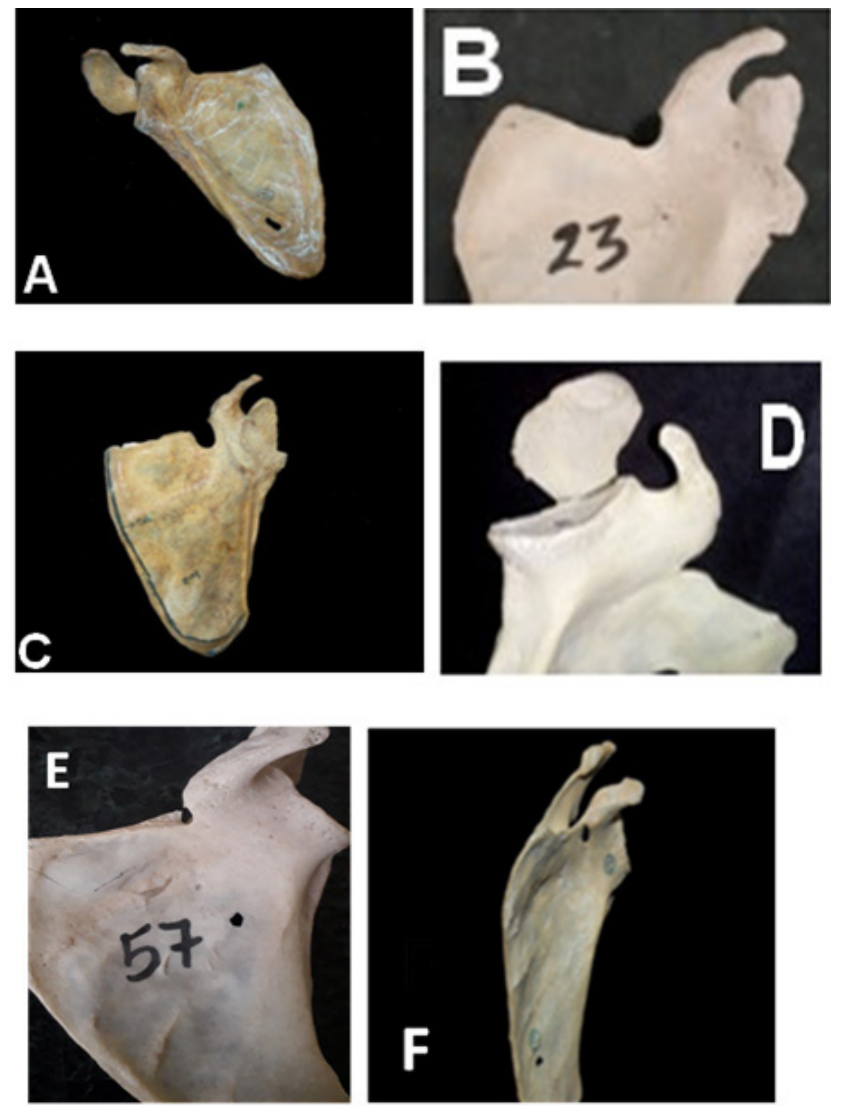

Figure 2: Scapulae showing different morphological variations of suprascapular notches in the superior border (A: type I / slight indentation; B: type II / wide blunt V-shaped; C: type III / U shaped; D: type IV / narrow V-shaped \& E: type V / incomplete suprascapular foramen; F: type VI / complete suprascapular foramen).

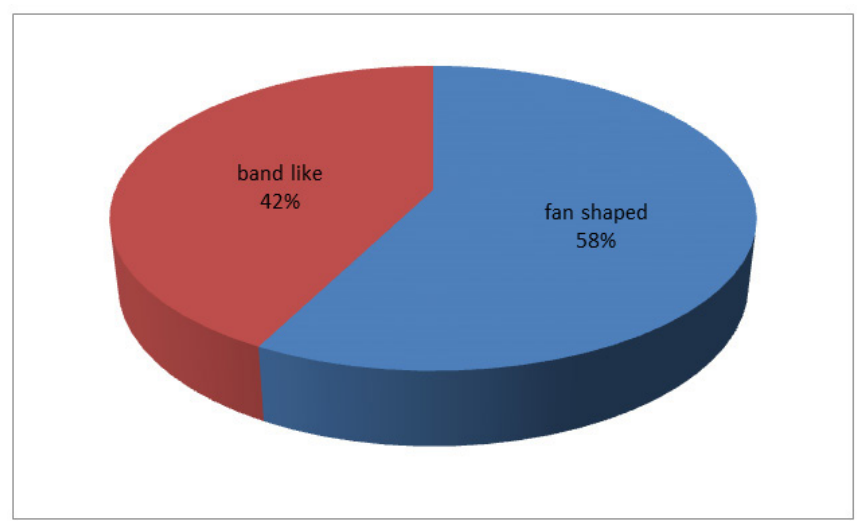

Figure 3: Graphical representation of the incidence of the various morphological pattern of ossified STSL in the present study.
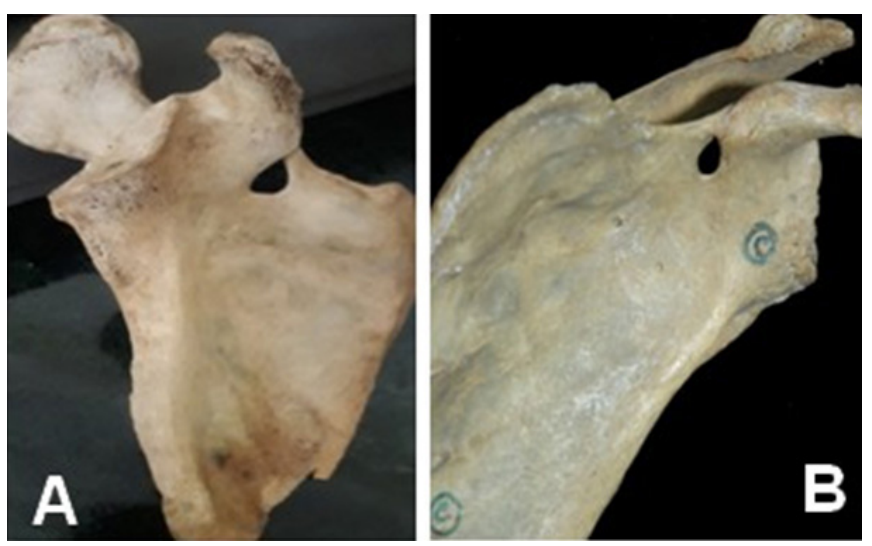

Figure 4: Scapulae displaying the morphological variations of STSL (A band like; B fan-shaped). 